\title{
GENERAL TECHNICAL EDUCATION IN PRIMARY SCHOOLS IN THE CONTEXT OF THE REQUIREMENTS OF OCCUPATIONAL SAFETY AND HYGIENE
}

\author{
Jozef PA VELKA
}

\begin{abstract}
The study deals with developments in conditions of safety and hygiene in the general technical education in primary school in the previous period and the present. It presents information on the conditions of safety and hygiene of students in the context of systemic change teaching subjects working classes, technical education and technology.
\end{abstract}

Key words: general technical education, primary school, safety and hygiene.

\section{VŠEOBECNÉ TECHNICKÉ VZDELÁVANIE V ZÁKLADNÝCH ŠKOLÁCH V KONTEXTE POŽIADAVIEK BOZP A PO}

Resumé: Štúdia sa zaoberá vývojom podmienok BOZP a PO v rámci všeobecného technického vzdelávania v základnej škole $\mathrm{v}$ predošlom období i v súčasnosti. Prezentuje informácie o podmienkach BOZP žiakov v kontexte systémových zmien výučby predmetov Pracovné vyučovanie, Technická výchova a Technika.

Kl'účové slová: všeobecné technické vzdelávanie, základná škola, bezpečnost' a hygiena práce.

\section{1 Úvod}

Zákon o bezpečnosti a ochrane zdravia pri práci a o zmene a doplnení niektorých zákonov, ktorý nadobudol účinnost' 1. 7. 2006 posilnil systémovú komplexnost' právnej úpravy bezpečnosti a ochrany zdravia pri práci (BOZP), čím sa má dôslednejšie zabezpečit' BOZP, vylúčenie alebo zníženie počtu vzniku pracovných úrazov, chorôb z povolania a iných poškodení zdravia z práce. Uvedený zákon platí tak pre výrobnú sféru, ako aj pre oblast' výchovno-vzdelávaciu. Aj v predchádzajúcom období platili zákony a z týchto vyplývajúce vyhlášky, opatrenia, normy pre oblast' BOZP. V nasledujúcom budeme prezentovat' tie vybrané oblasti všeobecného technického vzdelávania v základnej škole, ktoré bezprostredne súviseli a súvisia s dodržiavaním podmienok BOZP.

\section{Podmienky BOZP vo všeobecnom technickom vzdelávaní $v$ základnej škole \\ Všetky vzdelávacie zariadenia (školské i mimoškolské) majú $v$ oblasti bezpečnosti a hygieny práce dve základné povinnosti: \\ a) Vychovávat' učiacich sa jednotlivcov (žiakov, študentov) $\mathrm{k}$ bezpečnosti a hygiene práce a $\mathrm{k}$ bezpečnému správaniu. \\ b) Zabezpečit' podmienky pre bezpečnú} a zdraviu nezávadnú prácu učiacich sa jednotlivcov, vyučujúcich a ostatných pracovníkov vzdelávacieho zariadenia.

Realizácia všeobecného technického vzdelávania v ZŠ si vyžaduje zabezpečenie podmienok BOZP pre tieto oblasti:

1. Obsah a špecifické ciele vzdelávania

2. Priestorové zabezpečenie vzdelávania

3. Materiálno-technické zabezpečenie vzdelávania

Spôsob zabezpečovania podmienok BOZP $\mathrm{v}$ uvedených oblastiach $\mathrm{v}$ predchádzajúcom období a v súčasnosti sa z historického aspektu realizoval takto:

Pre vyučovací predmet Pracovné vyučovanie v 5. až 9. roč. ZŠ do šk. r. 1996/1997

\section{Obsah a špecifické ciele vzdelávania \\ - stanovené učebnými osnovami vyučovacieho predmetu pre jednotlivé ročníky v súlade s vekovými osobitost'ami žiakov \\ Priestorové zabezpečenie vzdelávania}

- ručná kovodielňa, ručná drevodielňa, učebňa elektromontážnych prác, príručný sklad, sklad (príp. prípravovňa) materiálov a polotovarov, šatňa žiakov, kabinet učitel'a, hygienické priestory, 
- bolo projektované Inžinierskoprojektovou organizáciou školských stavieb (IPO ŠS) do jej zániku v r. 1990.

Materiálno-technické zabezpečenie vzdelávania

- nákup a centrálne dodávky učebných pomôcok (UP) zo š. p. Učebné pomôcky B. Bystrica (do r. 1990),

- individuálne zhotovovanie UP učitel'mi, údržba UP a dodávky polotovarov z Okresných technických a materiálových stredísk, (OTMS), neskôr Stredísk služieb škole (SSŠ).

Materiálno-technické zabezpečenie vzdelávani Pre vyučovací predmet Technická výchova v 5. až 9. roč. ZŠ od šk. r. 1997/1998 do šk. r. 2007/2008

\section{Obsah a špecifické ciele vzdelávania}

- stanovené učebnými osnovami predmetu z r. 1997 pre jednotlivé ročníky v súlade s vekovými osobitost’ami žiakov,

- podstatne modernizovaný obsah (nová učebnica) a špecifické ciele vzdelávania (prvý vzdelávací štandard z r. 2003).

\section{Priestorové zabezpečenie vzdelávania}

- postupné znižovanie priestorového zabezpečenia, priestory školami využívané na iné účely, premiestňovanie dielní do iných priestorov v rámci školy,

- nedochádza k zriad'ovaniu špecializovanej učebne (napr. Laboratórium techniky) pre výučbu nových vzdelávacích obsahov ( napr. Človek a technika, Stroje a mechanizmy, Prostriedky malej ručnej mechanizácie, Údržba domácnosti, Naučme sa hospodárit' a pod.),

- od r. 2000 právna subjektivita škôl (Vedenia škôl riešia skôr akútne problémy školy).

Materiálno-technické zabezpečenie vzdelávania

- obmedzovanie výdavkov škôl na nákup UP,

- zrušenie centrálnych dodávok pomôcok UP zo š. p. Učebné pomôcky B. Bystrica z dôvodu jeho zániku,

- novovzniknutá firma UP SLOVAKIA, B. Bystrica $\mathrm{v}$ ponukovom katalógu nemá žiadne UP pre výučbu Techniky,

- zrušenie OTMS, resp. SSŠ,

- novovzniknuté SSŠ v niektorých regiónoch Slovenska činnost' zamerali skôr na údržbu školských stavieb,

- takmer žiadne dovybavenie škôl UP pre výučbu nových vzdelávacích obsahov.
Pre povinný ai volitel'ný vyučovací predmet Technika v 5. až 9. roč. ZŠ do šk. r. 2008/2009 doposial'

\section{Obsah a špecifické ciele vzdelávania}

- v šk. r. 2008/2009 až 2010/2011 Štátnym vzdelávacím programom (ŠVP) stanovené obsahové a výkonové štandardy pre 7. a 8. roč. ZŠ pre určené tematické okruhy - Človek a technika, Grafická komunikácia, Materiály a technológie - v 7. roč. a Elektrická energia a Technika - domácnost' bezpečnost' $-\mathrm{v} 8$. roč. (povinný predmet Technika),

- v rovnakom období Štátnym vzdelávacím programom (ŠVP) stanovené obsahové a výkonové štandardy pre 5. až 9. roč. ZŠ pre určené tematické okruhy - Človek a technika, Konštruovanie a navrhovatel'ské činnosti, Ako veci fungujú a Materiály a technológie (volitel'ný predmet Technika),

- počnúc šk. r. 2011/2012 úpravou Rámcového učebného plánu sa rovnaký obsahový a výkonový štandard povinného predmetu Technika stal platný pre všetky ročníky 5 . až 9 .

\section{Priestorové a materiálno-technické zabezpečenie vzdelávania}

Vzhl'adom na závažnost' a rozsah zmien vo všeobecne technickom vzdelávaní, ku ktorým došlo od r. 1997 a najmä realizáciou školskej reformy, uskutočnili sme v mesiaci máj 2011 empirický výskum v ZŠ v SR. Hlavným ciel'om výskumu bolo prostredníctvom elektronického dotazníka zistit' podrobnejšie informácie o skutočnom stave realizácie technického vzdelávania $\mathrm{v}$ nižšom sekundárnom vzdelávaní v tret'om roku prebiehajúcej školskej reformy. Podrobne informácie o predmetnom výskume sme zverejnili v inej štúdii. Z celkového počtu 640 registrovaných učitel'ov Techniky na Portáli EduTech sa do prieskumu zapojilo 179 respondentov, čo predstavuje $28 \%$ návratnost' dotazníkov základného súboru.

Ked’že $v$ tejto štúdii nie je priestor na podrobnú analýzu všetkých výsledkov výskumu, v nasledujúcom uvedieme len vybrané, pritom podstatné čiastkové výsledky, ktoré majú priamu súvislost' so zabezpečovaním podmienok BOZP v školách. 


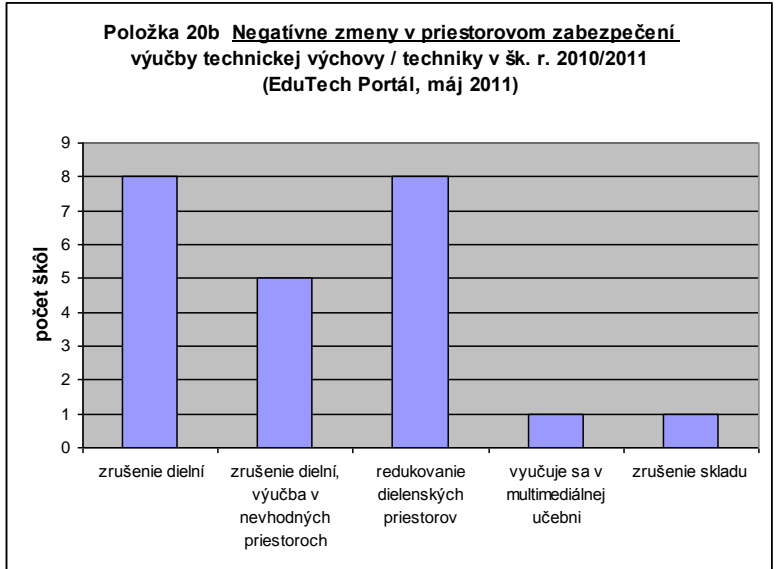

Graf 1: Odpovede respondentov na položku $20 \mathrm{~b}$

V oblasti materiálno-technického a priestorového zabezpečenia výučby Techniky výsledky prieskumu (grafy 1 a 2) potvrdzujú dlhodobo pokračujúce d’alšie zhoršovanie podmienok pre jej výučbu. Z celkového počtu 179 škôl za pozitíva v materiálno-technickom zabezpečení označilo len $10 \%$ respondentov (18 škôl) najmä dovybavenie predmetu nástrojmi a náradím (9 škôl), výpočtovou technikou (4 školy) a školským nábytkom (5 škôl).

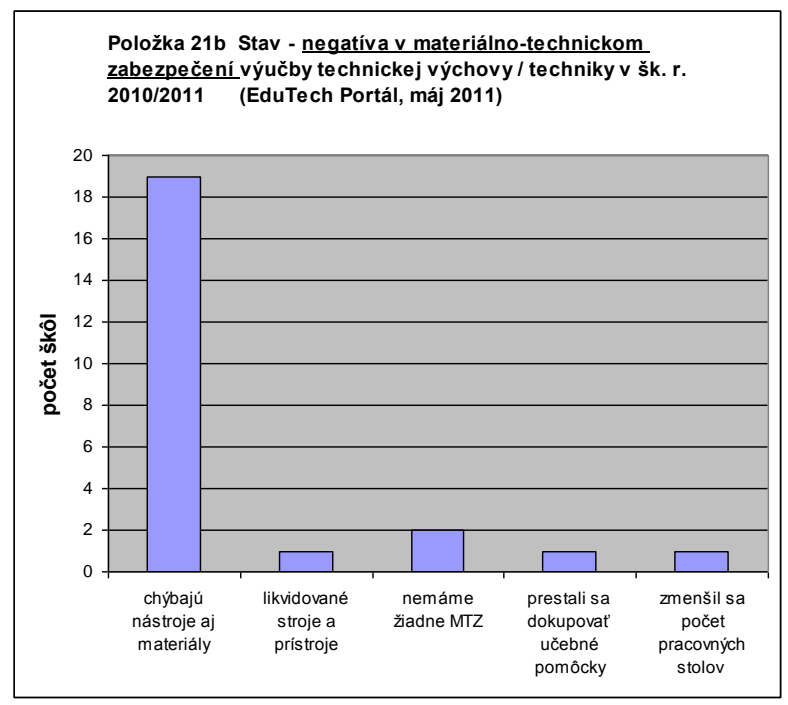

Graf 2: Odpovede respondentov na položku $21 \mathrm{~b}$

$\mathrm{Na}$ realizáciu výučby povinného predmetu Technika v 7. roč. ZŠ v prvom roku zavedenia tohto predmetu v školách v zmysle ŠVP, respondenti hodnotili materiálno-technické zabezpečenie (graf 3, položka 22 dotazníka) pre výučbu napr. tematického okruhu Materiály a technológie takto: výborné - 17 (9,49\%), vel'mi dobré - $29(16,20 \%)$, dobré - $65(36,31 \%)$, uspokojivé - $44(24,58 \%)$ a nedostatočné - 24
$(13,40 \%)$ respondentov. Podobne v položke 23 dotazníka $57 \quad(31,84 \%)$ respondentov spolu hodnotilo, že materiálno-technické podmienky na výučbu tematického okruhu Ako veci fungujú ako neuspokojivé až nedostatočné.

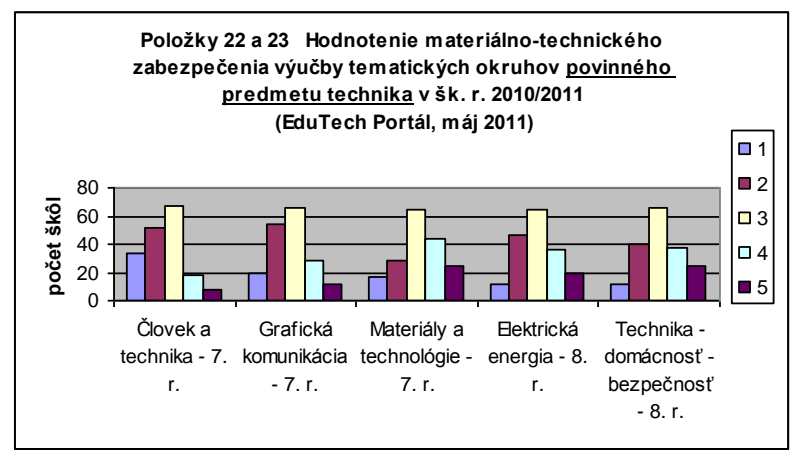

Graf 3: Odpovede respondentov na položku 22.

Čiastkové výsledky výskumu poukazujú na zhoršujúcu sa situáciu v priestorovom a materiálno-technickom zabezpečení výučby techniky v základných školách.

Štatistické výsledky úrazovosti žiakov v základných školách [1] sú nasledujúce:

Úrazovost' detí, žiakov a študentov podl'a kritérií:

* základná škola

* drobné zranenie a bežný úraz

* náradie, nástroje, ručne ovládané strojčeky a prístroje

Šk. rok: 2008/9 2009/10 2010/11 2011/12

Počet

úrazov: $119 \quad 95 \quad 81 \quad 34$

Počet

Škôl: $\quad 75 \quad 50 \quad 41 \quad 26$

Podrobnejšia analýza klesajúceho počtu úrazov žiakov nie je k dispozícii, nie je teda možné tvrdit', že počty úrazov predstavujú úrazy žiakov, ku ktorým došlo na hodinách Techniky. Uvedené ale evokuje otázku: Nemá klesajúca tendencia úrazovosti žiakov priamy súvis slikvidáciou priestorového a materiálnotechnického vybavenia predmetu Technika?

Na základe d’alších našich zistení a informácií získaných z reálnej školskej praxe pre vymedzené oblasti všeobecného technického vzdelávania na nižšom stupni sekundárneho vzdelávania $\mathrm{v}$ zmysle požiadaviek BOZP je nevyhnuté čo najskôr zabezpečit' nasledujúce: 
a) voblasti obsahu a špecifických ciel'ov vzdelávania:

- skúmat' a legislatívne stanovit' obsahové zameranie, rozsah tematických okruhov a výkonové požiadavky vzdelávania s akcentom na vekové osobitosti žiakov, ich záujmy, potreby a vlohy a spoločenské potreby

b) voblasti priestorového a materiálnotechnického zabezpečenia vzdelávania:

- v spolupráci s napr. jestvujúcou a.s. IPO školských stavieb Bratislava vypracovat' a do praxe zaviest' normatívy, ktoré pre ZŠ stanovia základné učebné priestory pre teoretické a praktické vyučovanie a ich základné materiálne a prístrojové vybavenie,

- $\quad$ v spolupráci s Krajskými školskými úradmi (KŠÚ) zabezpečit' zriadenie regionálnych Stredísk služieb škole (okrem regiónov, v ktorých jestvujú) a dosiahnut' rozšírenie predmetu ich súčasnej činnosti o systémovú a komplexnú činnost' zameranú aj na zabezpečovanie škôl potrebnými technickými materiálmi, polotovarmi, prístrojmi a zariadeniami,

- docielit', aby MŠVV a Š SR legislatívne zaviazalo vedenia škôl každoročne z normatívov pre školy a školské zariadenia (vzdelávacieho poukazu) vyčlenit' čast' finančných prostriedkov na podporu rozvoja technického vzdelávania v ZŠ,

- spoluprácou fakúlt vysokých škôl pripravujúcich učitel'ov s napr. firmou UP SLOVAKIA v B. Bystrici a učitel'mi ZŠ vytvorit' podmienky na vývoj, výskum a distribúciu špecifických učebných pomôcok, docielit' účinnú kontrolu priestorového a materiálno-technického vybavenia základných škôl zo strany Štátnej školskej inšpekcie, ako aj Inšpektorátom bezpečnosti práce. V prípade zistenia závažných nedostatkov prijat' účinné opatrenia a vyvodit' napr. aj personálne postihy a dôsledky.

\section{Záver}

So zámerom dat' podnety na širšiu diskusiu $\mathrm{k}$ problematike BOZP $\mathrm{v}$ základných školách na záver uvedieme otázku:

Akú dimenziu dat' všeobecnému technickému vzdelávaniu a ako vôbec zabezpečit', aby človek - žiak:

- osvojil si základné princípy a pravidlá BOZP platné pre používanie rôznorodých náradí, nástrojov a prístrojov a vykonávanie rôznorodých manuálnych činností v škole i v bežnom živote?

- disponoval dostatočným súborom základných vedomostí a praktických zručností, ktoré budú dôležitým východiskom a základom pre jeho život, d’alšie štúdium a pre uplatnenie sa na trhu práce?

4 Literatúra

[1] ÚIPŠ MŠ VV a Š SR. [online]. [cit. 2012-03-

06]. Dostupné na internete:

<http://web.uips.sk/urazy/>

prof. PaedDr. Jozef Pavelka,CSc.

Katedra fyziky, matematiky a techniky

Fakulta humanitných a prírodných vied

Prešovskej univerzity v Prešove

Ul. 17. novembra č. 1

08001 Prešov

E-mail: pavelkj0@unipo.sk 